\title{
O protagonismo dos Conselhos de Secretários Municipais no processo de governança regional
}

\author{
The prominent role of Councils of Municipal Health Secretariats \\ in the regional governance process
}

Helena Eri Shimizu ${ }^{1}$

Mariana Sodário Cruz ${ }^{1}$

Nilo Bretas Júnior ${ }^{1}$

Sergio Ricardo Schierholt ${ }^{1}$

Walter Massa Ramalho ${ }^{1}$

Maíra Catharina Ramos ${ }^{1}$

Monique Santos Mesquita ${ }^{1}$

Everton Nunes Silva ${ }^{1}$

${ }^{1}$ Departamento de Enfermagem, Faculdade de Ciências da Saúde, Universidade de Brasília. Asa Norte, Campus Darcy Ribeiro. 70910-900 Brasília DF Brasil.shimizu@unb.br
Abstract This study aims to analyze the perception of managers of the Councils of Municipal Health Secretariats (COSEMS) and their contributions to the health regionalization process. We conducted thorough interviews with presidents of COSEMS of the states of Mato Grosso do Sul, Paraná, Ceará, Tocantins and Minas Gerais. Data were analyzed with Iramuteq software, which generated a dendrogram with three themes: The first thematic axis: the prominent role of COSEMS in the regional governance process, which includes class 1 - COSEMS' leadership in the process of regionalization, and class 3 - The strategic experience of the regional agreement process. The second thematic axis includes the challenges to the provision of health care in the regions, consisting of class 2, which shows how to meet community needs, and class 4, which shows the local support carried out by COSEMS' teams. The third thematic axis consists of class 5, which describes the operational aspects of the provision of health care in the region. COSEMS play an important role in the regionalization process, especially because they have an organic performance and leadership. Its organic performance in these areas has ensured its legitimacy and leadership. It is a daily construction that ensures the advancement of collaborative governance in health regions.

Key words Regionalization, Governance, Health
Resumo $O$ estudo tem como objetivo analisar a percepção dos gestores dos Conselho de Secretários Municipais (COSEMS) e as suas contribuições para o processo de regionalização em saúde. Foram realizadas entrevistas em profundidade com os presidentes dos COSEMS dos Estados de Mato Grosso do Sul, Paraná, Ceará, Tocantins e Minas Gerais. Os dados analisados com o "software Iramuteq", que gerou um dendograma com o primeiro eixo temático: o protagonismo dos COSEMS no processo de governança regional que contém a classe 1, a liderança do COSEMS no processo de regionalização, e a classe 3, a experiência estratégica do processo de pactuação regional. E o segundo eixo temático, os desafios para provisão da atenção à saúde nas regiões, composto pela classe 2, que aborda como atender as necessidades da comunidade, e pela classe 4, que demonstra o apoio local realizado pelas esquipes dos COSEMS. O terceiro eixo temático, composto pela classe 5, descreve os aspectos operacionais da provisão da atenção à saúde na região. No processo de regionalização, os COSEMS têm importante protagonismo, sobretudo porque possuem atuação orgânica e liderança. Trata-se, pois, de construção cotidiana que garante o avanço da governança colaborativa nas regiões de saúde.

Palavras-chave Regionalização, Governança, Saúde 


\section{Introduction}

In Brazil, health management decentralization to the municipal entity is understood as a strategy of democratization and incorporation of new stakeholders in order to ensure greater participation of municipalities ${ }^{1}$. Among advances achieved, we can highlight the expanded access of the population to services, mainly Primary Health Care, and the considerable improvements of national health indicators ${ }^{2}$. Among hardships, the unequal political, technical, financial and health conditions of the Brazilian municipalities made the process extremely complex. Competition between the federated entities sometimes prevented the necessary municipal autonomy in the management of existing equipment in its territorial limits and in the available financial resources ${ }^{2}$.

However, even considering the difficulties in accurately measuring the improvements resulting from decentralized management actions and health services, it is clear that this process represented advances in the formulation of public health policies when a large number of different stakeholders were gathered and distributed throughout the national territory, most of them linked to the municipal sphere, since they began to assume more directly the provision of the right to health ${ }^{3-5}$.

However, it has been verified that municipalities alone cannot provide all the actions and services required by the population to ensure comprehensive care, due to insufficient financial and human resources, logistics and population size, since some $50 \%$ of Brazilian municipalities have a population of less than ten thousand inhabitants. In addition, it has been recognized for some time that municipalization, in part, has contributed to the fragmentation of the health care system, which could be overcome by regionalization $^{5}$. From this perspective, based mainly on the greater rational use of resources, the topic of health regionalization has been assuming greater importance in the debate on the improvement of the policies within the Unified Health System (SUS) ${ }^{6}$.

Thus, after accumulating more than two decades of successive federal regulations aimed at inducing decentralization (in the 1990s, four Basic Operational Standards (NOB) were published); in 2001, the Operational Health Care Standard (NOAS, reformulated in 2002); in 2006, the Pact for Health) and, more recently, re- gionalization, with the publication of Decree No 7.508/11, which defines the need for regionalization with the purpose of rationalizing resources and ensuring comprehensive care for the entire Brazilian population ${ }^{7}$. However, there are great difficulties to operationalize such Decree, which requires stronger political investments to advance the process of decentralization and health regionalization in the country.

The Councils of Municipal Health Secretariats (COSEMS), which were created to reinforce the municipalization process, have been working emphatically in recent times to resolve the health system's fragmentation in order to provide the necessary actions and services for the population. From this perspective, these stakeholders have identified regionalization as a possible course. However, the regionalization process is not an easy task, since it is a political arena where several projects are disputed ${ }^{8}$.

Decree $n^{\circ}$ 7.508/11 defines the "Health Region as a continuous geographic space consisting of clusters of bordering municipalities, delimited by cultural, economic and social identities and shared communication networks and infrastructure transport, whose purpose is to integrate the organization, planning and execution of health actions and services, aiming at ensuring comprehensive health care".

Regionalization is a permanent political structure of decentralization with the participation of all federated entities, in a process of agreement and shared responsibilities of a health region, in the logic of health territory $y^{10-13}$. Thus, as a health region, regionalization must be consolidated not only based on standards, but also mainly on practices, the scope of actions and services and shared responsibility.

However, health regions characteristics are heterogeneous, which reflect the different financial, administrative and operational capacities for the delivery of health care. In this context, COSEMS have undertaken the arduous task of helping to manage a heterogeneous and institutionally non-integrated service network whose supply is insufficient, especially medium complexity services. Few studies investigate the actions of COSEMS in the regionalization process, but are strategic players in the daily construction of this process with the municipalities.

Thus, this study aims to analyze the perception of COSEMS' presidents on the regionalization process, as well as its weaknesses and potentialities. 


\section{Methodology}

This is a qualitative study carried out with COSEMS in the states of Mato Grosso do Sul, Paraná, Ceará, Tocantins and Minas Gerais. These states were intentionally chosen because of the unique investments made in the regionalization process, more closely following the normative and legal framework established for governance in the SUS.

We conducted in-depth interviews with COSEMS' presidents, hereinafter called COSEMS' managers, who had at least three months' office experience and outstanding performance in the municipalities. COSEMS' presidents with less than three months experience and with low performance with the municipalities were excluded.

A semi-structured interview script was used that addressed the following aspects: the role of COSEMS in the regionalization process, the regionalization process, the construction of regional planning, as well as the participation of municipalities in regional planning and the participation of councils within the framework of regionalization. It should be emphasized that respondents could talk freely about these topics. Interviews lasted about 60 minutes and were all transcribed in full.

Data analysis was performed with IRAMUTEQ, version 0.6. It is a free computer program that performs different types of textual data analysis, such as basic lexicography that calculates word frequency, to multivariate analysis, such as the descending hierarchical classification ${ }^{14}$.

The Descending Hierarchical Classification (DHC) method was performed in this study, highlighting words, frequency with which they appear and their associations in word class, which allows us to highlight the common or more consensual field for the social group studied. Classes generated from this method represent the words meaning's context and can demonstrate representations or elements of representations about a particular social object ${ }^{14}$.

In other words, the software emphasizes lexical worlds of full-blown words that refer to the same meaning core. A kind of text structure produced by a group of subjects that demonstrates certain "shared semantics about the same object". The dendrogram of Figure 1 synthesizes the axes and classes of highlighted words, but which require hermeneutical analysis to understand the text and the meaning production context.

Another analysis performed by the software was similarity analysis, shown in Figure 2, which makes it possible to identify co-occurrences between words, and its result indicates connectivity between the words, which facilitates the identification of the object representation's structure for the subjects involved ${ }^{14}$.

The research project was approved by the Research Ethics Committee of the Faculty of Health Sciences and all participants signed the Informed Consent Form.

\section{Results}

In this study, the five interviews analyzed had $71.22 \%$ use of the IRAMUTEQ software, which is satisfactory ${ }^{14}$. The first thematic axis, known as "COSEMS predominant role in the regional governance process", contains classes 1 and 3. Class $1(15.9 \%)$ addresses COSEMS' leadership in the regionalization process, and class 3 (19.6\%) addresses the strategic experience of the regional pacts process. The second thematic axis, composed of classes $2(24 \%)$ and $4(21.9 \%)$ was called "Challenges to the provision of healthcare in the regions". The third thematic axis consists only of class 5 (18.5\%). Class 2 addresses how community needs are met, class 4 examines the local support provided by COSEMS' teams, and finally class 5 describes the operational aspects of health care provision in the region.

Regarding the first thematic axis, class 1 addresses the importance of COSEMS leadership in the regionalization process, which includes its role of coordinating the various stakeholders participating in this governance. Some spaces are perceived by COSEMS' managers as strategic for the formulation and operationalization of health regional policies and actions. First, the meetings of councils of municipal secretaries in the regions are useful spaces for sharing regional decision-making. In addition, sponsors are considered key figures to solve the problems of daily life, giving the necessary support to municipalities. Second, CIRs are also powerful locus for the agreement of actions and services needed for the regions. The organization of meetings to discuss issues related to the region are essential for sharing collective decision-making in order to meet the needs of the population. Third, CIBs have facilitated the regional governance process, however, they consider that the conduction of agendas has been very centralized, which has prevented COSEMS from playing a greater role. Fourth, health councils are also perceived as important players in decision-making within the health 


\begin{tabular}{|c|c|c|c|c|}
\hline class 1 & class 3 & class 5 & class 2 & class 4 \\
\hline $15.9 \%$ & $19.6 \%$ & $18.5 \%$ & $24 \%$ & $21.9 \%$ \\
\hline $\begin{array}{l}\text { Manager } \\
\text { COSEMS } \\
\text { meeting } \\
\text { CRESEMS } \\
\text { sponsor } \\
\text { CIR } \\
\text { municipal } \\
\text { president } \\
\text { theme } \\
\text { program } \\
\text { see } \\
\text { directorate } \\
\text { call } \\
\text { board } \\
\text { CIB } \\
\text { past } \\
\text { continued education } \\
\text { publish } \\
\text { evolve } \\
\text { gather } \\
\text { institution } \\
\text { management } \\
\text { participate } \\
\text { work } \\
\text { after } \\
\text { last } \\
\text { pathway } \\
\text { inclusive }\end{array}$ & $\begin{array}{l}\text { Ceará } \\
\text { point } \\
\text { view } \\
\text { intense } \\
\text { agreement } \\
\text { finally } \\
\text { health } \\
\text { time } \\
\text { political } \\
\text { experience } \\
\text { large } \\
\text { long } \\
\text { strategic } \\
\text { important } \\
\text { mandate } \\
\text { close } \\
\text { unified health system } \\
\text { idea } \\
\text { school } \\
\text { conflict } \\
\text { home } \\
\text { mode } \\
\text { education } \\
\text { management } \\
\text { perspective } \\
\text { historically } \\
\text { assume }\end{array}$ & $\begin{array}{l}\text { Care } \\
\text { test } \\
\text { consultation } \\
\text { complex } \\
\text { urgency } \\
\text { basic } \\
\text { real } \\
\text { primary } \\
\text { regulator } \\
\text { emergency } \\
\text { table } \\
\text { cost } \\
\text { facility } \\
\text { pass } \\
\text { hand } \\
\text { high } \\
\text { month } \\
\text { meet } \\
\text { money } \\
\text { MAC } \\
\text { drug } \\
\text { equipment } \\
\text { week } \\
\text { cost } \\
\text { open }\end{array}$ & $\begin{array}{l}\text { See } \\
\text { try } \\
\text { community } \\
\text { people } \\
\text { different } \\
\text { problem } \\
\text { legal } \\
\text { need } \\
\text { know } \\
\text { talk } \\
\text { speak } \\
\text { achieve } \\
\text { come } \\
\text { relationship } \\
\text { sit } \\
\text { with } \\
\text { study } \\
\text { train } \\
\text { now } \\
\text { time } \\
\text { sign } \\
\text { hour } \\
\text { negotiate } \\
\text { stop }\end{array}$ & $\begin{array}{l}\text { Over there } \\
\text { view } \\
\text { team } \\
\text { condition } \\
\text { different } \\
\text { provide } \\
\text { case } \\
\text { so } \\
\text { arrive } \\
\text { business } \\
\text { professional } \\
\text { right } \\
\text { other } \\
\text { actually } \\
\text { totally } \\
\text { provide } \\
\text { side } \\
\text { function } \\
\text { technician } \\
\text { your } \\
\text { teach } \\
\text { care } \\
\text { totality } \\
\text { level } \\
\text { skill }\end{array}$ \\
\hline
\end{tabular}

Figure 1. Dendrogram about the perception of COSEMS' presidents about the health regionalization process.

regions; however, there is a need to invite them more emphatically to join this arena, as their participation is quite scarce in the health regions, since the focus still is on municipalities or states.

Regarding class 3, concerning the experience of regionalization, Ceará case stands out and is classified by COSEMS' managers as intense from the standpoint of the agreement and sharing of actions and services. However, it has also been perceived as a space for disputes and conflicts, although it is an important strategy for the establishment of health system governance. Finally, it is mentioned that this historical experience brought new perspectives to SUS management.

In the second thematic axis, class 5 deals with the operational aspects of health care provision in the region. COSEMS has been active in ensuring access to the necessary health services by the population of the region, ranging from the basic services (consultations, tests, procedures) provided by Primary Health Care (PHC) to specialized urgent and emergency services. This is an extremely complex task. Hence, it is worth highlighting the financial hardships to pay for actions and services, which are expensive, especially those inherent to medium and high complexity, besides medicines. This time, there is a need to rationalize scarce resources.

Class 2 addresses the role of COSEMS in articulating and negotiating the provision of actions and services to health regions. It is evident that there are great difficulties to share the actions and necessary health services (consultations, tests, procedures and medicines). Some municipalities have better infrastructure for public health services than others do. However, the availability to help the municipality with less capacity is varied, as well as the forms of provision 


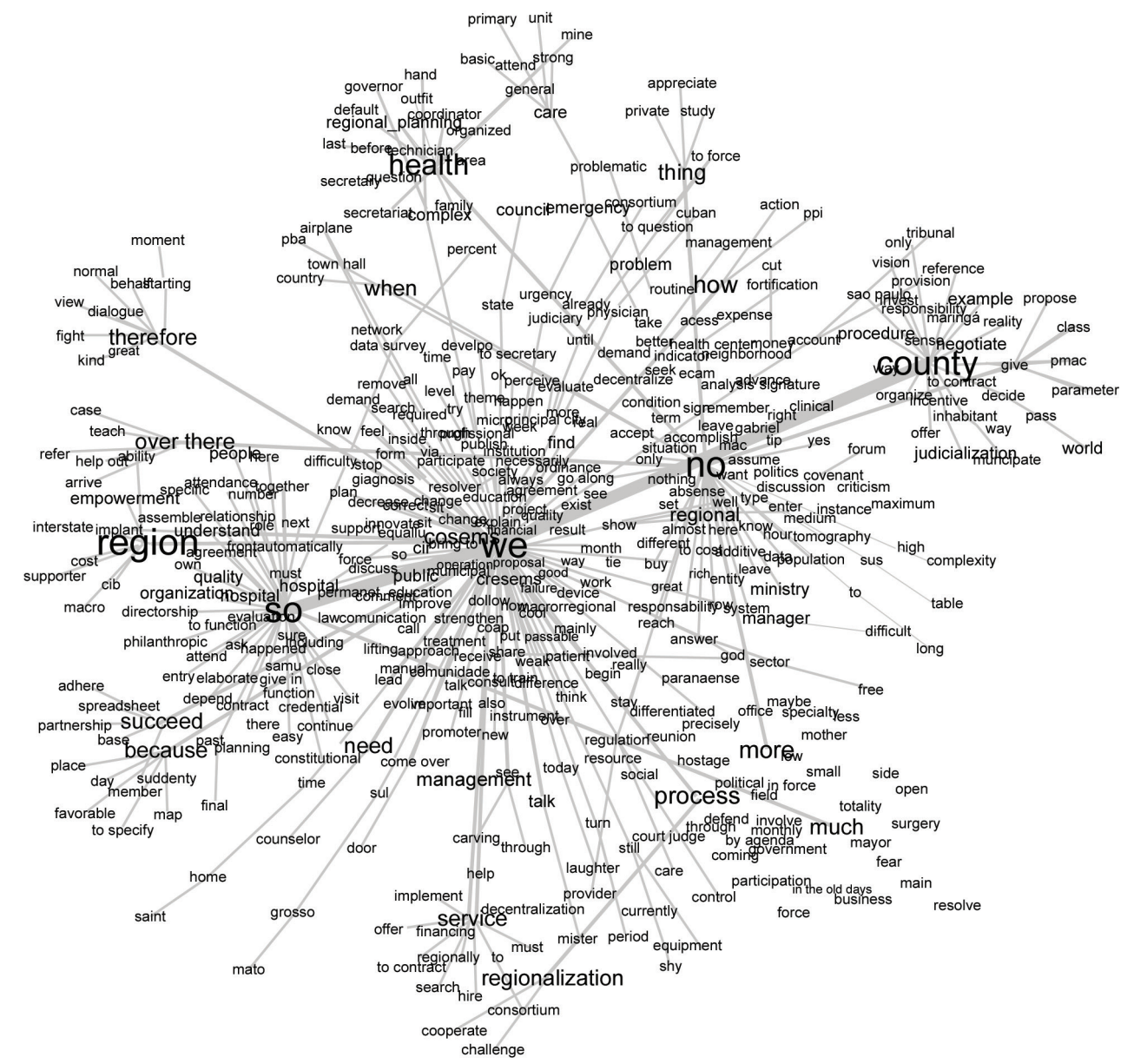

Figure 2. Similarity analysis of the health regionalization process.

of actions and services. For example, some regions have a tradition of operating through consortia. Other regions choose to negotiate services between municipalities. There is a great dependence on private services in several regions. Thus, in this class, it is demonstrated that COSEMS make efforts to meet the needs of the population, but they cannot always provide all the needs, thus the difficult task of constant dialogue with them.

Class 4 investigates COSEMS local support in the regions / municipalities, which, according to managers, involves being together (there) to see and equip. This is technical and logistical support, which also involves the training of professionals for the management of health regions.

The similarity analysis shown in Figure 2 highlights the word people at the center, which represents COSEMS' sponsors who are perma- nently linked with state, municipalities, health regions and the regionalization process itself.

\section{Discussion}

Results demonstrate that COSEMS' managers understand that the entity plays a relevant role in the regionalization process, especially as one of the stakeholders that contribute to the governance process of the health region. One of the limitations of this study concerns the qualitative method used, which facilitates understanding the process, but does not make it possible to generalize results. Another limitation is the reduced number of COSEMS' managers interviewed.

However, this study contributes to reflections on the actions of COSEMS, since regionaliza- 
tion is positively mainly associated to the level of articulation of COSEMS with the state health secretariats, regarding the distribution of management responsibilities and the regional designs adopted in each state ${ }^{10}$. In addition, the accumulated history of COSEMS in the interaction with municipalities, especially in the spaces of agreement of the SUS, Technical Chambers, Regional Interagency Commissions and the daily presence of sponsors in the regions has collaborated to make this coexistence an expression of life ${ }^{11-12,15}$. In the first thematic axis of this study, we pointed out several spaces and stakeholders that interact and agglutinate to develop regionalization, some through the leadership of COSEMS. Of these, regional COSEMS are highlighted as places that favor regional agreement, since they gather several municipal managers to state their needs and discuss the possibilities of sharing solutions ${ }^{11-12,15}$. In fact, this is where health needs of the population of the municipalities with diverse demands are decided and provided ${ }^{11-12,15}$.

The Regional Interagency Commissions are permanent decision-making spaces and were also considered powerful, mainly because they have provided a municipality access route to the locus of regionalization and, in part, increased their power in the agreement processes ${ }^{10}$. However, despite their power, these spaces are still insufficient, with fragile and time-consuming political construction for the dynamic daily reality, which requires swift and constant decisions ${ }^{10}$.

This study evidenced that the health councils are indispensable players, especially at state lev$\mathrm{el}$, but they have fragile participation in the process of regionalization. Hence, councils seem to reproduce practices developed in other spheres, notably in municipalities, except in some cases, of work that is bureaucratized and distant from the health needs of the population ${ }^{16-17}$. These data show the need to commit them more forcefully to this political arena. In addition, these councils have a greater dialogue with the population of the region and social movements, so that they take part of the territory where they live and participate in the construction of regional development ${ }^{16-17}$. From this perspective, it is understood that the regional consciousness and identity encompasses the identification of inhabitants with their region, both within and outside of $\mathrm{it}^{18-20}$. Studies show the positive effects of regional governance when it is culturally appropriate and participation is equitable, although it seems always difficult learning the needs of stigmatized and poor populations ${ }^{21}$.
Regarding CIB's activities, we identified that the important involvement of the state in the development of the health regions is recognized, however, the conduction of this process has occurred prescriptively, limiting the leading role and capacity of other stakeholders living together in the daily reality ${ }^{5,10,17}$. State's participation in the regionalization process is fundamental, although at times discrete to meet the needs of true regional development ${ }^{5}$. In fact, the regionalization process has undergone strong political induction by federal and state entities, with a predominance of a centralized agenda that may hamper loco-regional development ${ }^{5,10,17}$.

Notably, within the regions, it would be incumbent upon state governments to coordinate the planning process of which the municipalities are part as autonomous political entities ${ }^{13}$. In this logic, regionalization takes on a double perspective in the context of interfederative relationships: decentralization to states and centralization (or recentralization) to municipalities.

To this end, it is necessary to advance the construction of regional technical and political autonomy, recognizing regions as living and legitimate settings, capable of advancing more equitable decision-making between municipalities and reducing regional inequalities and improving access to health services to the population ${ }^{5,15-18}$.

This study evidenced that, despite the weaknesses of SUS governance bodies for the development of health regionalization, the pioneering experience of Ceará was emblematic, as a process involving several players for negotiation and agreement of decision-making for health regions $\mathrm{s}^{22}$. The diverse and intense participation of the various stakeholders in the decision-making process regarding the provision of regional needs proved to be very robust for the democratic exercise $^{22}$.

The Public Action Organizational Contract (COAP) signed by only two states to date, among which the state of Ceará, is considered a powerful and necessary tool to formalize the agreement of strategies, financing and actions and services for the regions ${ }^{22}$. However, as has also been seen in this study, there is a great fear of accountability, especially of municipalities, which already assume a number of charges, even greater than set forth in the legislation ${ }^{22}$. Hence, it is evident that the federated entities did not advance satisfactorily in the accountability of COAP-related commitments ${ }^{22}$. There is a need for further study on contractualization for the provision of the right to health to the population. 
Another aspect identified as obstacle to the regionalization process brought about more emphatically in the second thematic axis of this study were the hardships in the provision of health care in the regions. Among them, insufficient financing appears in a setting of project disputes and fragmentation of available resourc$\mathrm{es}^{2}$. In other words, changes in the allocation of resources from the implementation of decentralization have not been satisfactory to modify the pattern of inequality in access to health goods and services in different health regions. In this process, COSEMS' managers and other players responsible for the regionalization process are faced with the task of helping to manage a heterogeneous and non-integrated service network with an insufficient supply of services, especially at medium-complexity level ${ }^{1}$.

In addition, we have to question that the implementation of policies defined by the federal and state spheres, on the one hand, has been viewed as a negative point, since the municipality feels compelled to expand its services to obtain a larger transfer, since these policies are linked to financial incentives. This increases the responsibility of municipalities, especially in relation to the commitment of the municipal budget beyond the legal limits, as already discussed in this study. On the other hand, increased health expenditure and the implementation of measures related to the reorganization of care resulted more from responses to national initiatives than from local level initiatives. This points to the importance of policy-making by the central level in conducting local actions and, on the other hand, may reveal a limited municipal management or its technical insufficiency in proposing healthcare improvement actions.

There are several ways to provide actions and services to the regions. One is the regional consortium, which does not guarantee system integration, but has been a possible arrangement. This scheme has enabled the interaction between the different levels of care and smaller municipalities with medium or large municipalities, which is an important step to ensure access to other services and interaction between municipalities and the services that are provided by them, in order to allow a greater volume of health services and actions to the region ${ }^{1}$. Recent studies have identified consortia as a means of rationalizing scarce resources, particularly in drug procurement ${ }^{23,24}$.

Another form of providing actions and services are regional agreements, using the Integrated Agreed Programming (PPI) tools, but they are rather time-consuming and fragile. There is a need to revise flows and agreement of regional references, which are increasingly built in nonshared fashion, especially by the larger states and municipalities ${ }^{5}$.

We observed in this study that COSEMS' sponsors assist municipal managers in coping with the collections of health actions and services made by local communities, which cannot always be met $^{14}$. This involves the need for dialogue so that the community understands the limitations of management and, preferably, does not judicialize it. Judicialization costs, especially of drugs, have been exorbitant ${ }^{23}$, burdening municipalities and still disorganizing priority needs of the community itself. This is a complex daily issue, since most municipalities, especially small ones, are faced with lack of resources, community-related demand pressure, market pressure that involves technology fetishism, and political party action. This complexity requires efforts to strengthen regional governance.

This time, in addition to different possible provisions between regions, demands must be qualified, repressed demands must be satisfied and the "parallel SUS" must be resolved, which stems from the need for managers to buy services from other municipalities directly because they cannot meet their own demands within the region.

In addition, COSEMS' managers stated that they have assumed technical and operational support in the regions, which involves taking care of the region on a daily basis, through the provision of technological and human resourc$\mathrm{es}^{11,12}$. As demonstrated in the similarity analysis of this study, sponsors have strengthened the role of COSEMS, which, with creative and innovative capacity, enable many meetings, resulting in the construction of unique projects through solidarity in the regions; in addition to expanded autonomy of some regions and interconnected and quick information and decisions marked by debates within the scope of the CIRs ${ }^{11,12}$.

Despite the existing obstacles, Decree No 7.508/11 has made it possible to increase the intensity of the democratic process through the plurality of stakeholders involved in decision-making on the issues of concern. This type of democratic practice was idealized by participants in the Brazilian Health Reform, but still finds it difficult to be operationalized in social control spaces, especially health councils ${ }^{16,17}$. Notably, they have been rescued in other spheres of SUS governance, as well as in the regionalization construction spac- 
es, which requires solidarity among the federated entities, as a way of building fruitful interrelationships in the face of different regional and interregional characteristics, with a recognition of differences and the possibility of creating unique proposals for each micro-region ${ }^{13}$.

The practice of consensus building proposed by Habermas ${ }^{25}$, which privileges dialogue and communication, is necessary for this type of process. We must build what has been called collaborative governance that aims to gather various stakeholders into common forums to participate in consensus-oriented decision-making ${ }^{25}$.

The development of leadership is an essential element of governance, it is also necessary for the daily negotiation exercise to advance the process $^{26-28}$. In this logic, COSEMS, as a group of municipal managers interested in regional development, besides the rationality for the provision of health services offers, emerges as one of the strategic stakeholders for the construction of regionalization $^{11,12}$.

\section{Final considerations}

The results of this study allowed us to verify that governance of the regionalization process has raised some advances, in which COSEMS have an important role, especially since they are in connection with several areas of formulation and action, as well as strategic players of the SUS. However, the improvement of the regionalization process requires the articulation of all those involved in the organization of the regional health system. It is, therefore, a daily construction aimed at ensuring the advancement of collaborative governance in health regions. 


\section{Collaborations}

HE Shimizu participated in the conception of the study and data collection, analysis and discussion. MS Cruz and N Bretas Júnior participated in data collection and discussion; SR Schierholt and WM Ramalho participated in data discussion. MC Ramos e MS Mesquita participated in data organization. EN Silva participated in the paper's final review.

\section{References}

1. Pinafo E, Carvalho BG. Descentralização da gestão: caminho percorrido, nós críticos e perspectivas. Cien Saude Colet 2016; 21(5):1511-1524.

2. Duarte LS, Pessoto UC, Guimarães RB, Heimann LS, da Rocha Carvalheiro J, Cortizo CT, Ribeiro EAW. Regionalização da saúde no Brasil: uma perspectiva de análise. Saúde Soc 2015; 24(2):472-485.

3. Viana ALD, Lima LD. O processo de regionalização na saúde: contextos, condicionantes e papel das Comissões Intergestoras Bipartites. In: Viana AL d'Ávila, Lima LD, organizadores. Regionalização e relações federativas na política de saúde do Brasil. Rio de Janeiro: Contra Capa; 2011. p. 11-24.

4. Lima LD, Viana ALD, Machado CV, Scatena JHG, Kehrig RT, Spinelli MA. A regionalização da saúde no Brasil: condicionantes e desafios. In: Scatena JHG, Kehrig RT, Spinelli MA, organizadores. Regiões de Saúde: diversidade e processo de regionalização em Mato Grosso. São Paulo: Hucitec; 2014. p. 565.

5. Dourado DA, Elias PEM. Regionalização e dinâmica política do federalismo sanitário brasileiro. Rev saúde pública 2011; 45(1):204-211.

6. Kuschnir R, Chorny AH. Redes de atenção à saúde: contextualizando o debate. Cien Saude Colet 2010; 15(5):2307-2316.

7. Chebli ICF, Paiva MG, Stephan-Souza AI. O arcabouço jurídico-normativo do processo de descentralização e regionalização da saúde: percurso de sua consolidação. Revista APS 2010; 13(Supl. 1):75-83.

8. Mello GA, Ibañez N, Viana ALD. Um olhar histórico sobre a questão regional e os serviços básicos de saúde no Estado de São Paulo. Saúde Soc 2011; 20(4):853-866.

9. Brasil. Decreto no 7.508 , de 28 de junho de 2001. Regulamenta a Lei no 8.080, de 19 de setembro de 1990, para dispor sobre a organização do Sistema Único de Saúde - SUS, o planejamento da saúde, a assistência à saúde e a articulação interfederativa, e dá outras providências. Diário Oficial da União 2011; 29 jun.

10. Lima LD, Viana ALA, Machado CV, Albuquerque MV, Oliveira RG, Iozzi FL, Scatena JHG, Mello GA, Pereira AMM, Coelho APS. Regionalização e acesso à saúde nos estados brasileiros: condicionantes históricos e político-institucionais. Cien Saude Colet 2012; 17(11):2881-2892.

11. Peres AMMA, Dutra MJ, Santos MRC, Caldas M. Fontoura PR, Pinheiro R. Apoiadores Regionais: uma experiência brasileira. Rio de Janeiro: CEPESC, IMS/UERJ/ COSEMS/RJ, OPAS; 2014.

12. Carpintéro MCC. O Projeto Apoiadores e a regionalização: nossa alma e nosso labor. In: Pereira AL, Pereira Filho FNB, Monti JFC, Silveira LT, Louvison MCP, Pereira MTC, Akerman M, organizadores. Regionalização é o caminho: reflexões, diálogos e narrativas sobre as regiões de saúde no Estado de São Paulo. São Paulo: Phyxis Editorial; 2015. p. 28-35.

13. Machado CV, Lima LD, Viana ALA, Oliveira RG, Lozzi FL, Albuquerque MV, Scatena JHG, Mello GA, Pereira AMM, Coelho APS. Federalismo e polítca de saúde: comissões intergovernamentais no Brasil. Rev Saude 
Publica 2014; 48(4):642-650.

14. Camargo BV, Justo AM. IRAMUTEQ: um software gratuito para análise de dados textuais. Temas em Psicologia 2013; 21(2):513-518.

15. Pereira AL, Pereira MTC. Síntese das narrativas de apoiadores dos COSEMS/SP sobre a regionalização. In: Pereira AL, Pereira Filho FNB, Monti JFC, Silveira LT, Louvison MCP, Pereira MTC, Akerman M, organizadores. Regionalização é o caminho: reflexões, diálogos e narrativas sobre as regiões de saúde no Estado de São Paulo. São Paulo: Phyxis Editorial; 2015. p. 20-27.

16. Shimizu HE, Moura LM. As representações sociais do controle social em saúde: os avanços e entraves da participação social institucionalizada. Saúde Soc 2015; 24(4):1180-1192.

17. Shimizu HE, Silva JR, Moura LMM, Bérmudez XPD, Odeh MM. A estrutura das representações sociais sobre saúde e doença entre membros de movimentos sociais. Cien Saude Colet 2015; 20(9):2899-2910.

18. Spedo SM, Pinto NRS, Tanaka OY. A regionalização intramunicipal do Sistema Único de Saúde (SUS):um estudo de caso do município de São Paulo-SP, Brasil. Saúde Soc 2010; 19(3):533-546.

19. Silva EC, Gomes MHA. Impasses no processo de regionalização do SUS: tramas locais. Saúde Soc 2013; 22(4):1106-1116.

20. Mendes A, Louvison MCP, Ianni AMZ, Leite MG, Feuerwerker LCM, Tanaka OY, Duarte L, Weiller JAB, Lara NCC, Botelho LAM, Almeida CAL. O processo de construção da gestão regional da saúde no estado de São Paulo: subsídios para a análise. Saúde Soc 2015; 24(2):423-437.

21. Ciccone DK, Vian T, Maurer L, Bradley EH. Linking governance mechanisms to health outcomes: A review of the literature in low-and middle-income countries. Soc Sci Med 2014; 117:86-95.
22. Mascarenhas GC, Shimizu HE. Os Desafios do Planejamento Regional Compartilhado à Luz do Decreto ${ }^{\circ}$ 7.508: um estudo de caso Sobral - Ceará. In: Silva RM, Jorge MSB, Silva Junior AG, organizadores. Planejamento, gestão e avaliação nas práticas de saúde. Ceará: EdUECE; 2016. p.72-93

23. Amaral SMS, Blatt CR. Consórcio intermunicipal para a aquisição de medicamentos: impacto no desabastecimento e no custo. Rev Saude Publica 2011; 45(4):799801.

24. Diniz D, Machado TRC, Penalva J. A judicialização da saúde no Distrito Federal, Brasil. Cien Saude Colet 2014; 19(2):591-198.

25. Habermas J. Teoria de la acción comunicativa. Buenos Aires: Taurus; 1989. Vol. 2.

26. Forest PG, Denis JL. Real Reform in Health Systems: An Introduction. Journal of Health Politics, Policy and Law 2012; 37(4):576-586.

27. Ansell C, Gash A. Collaborative governance in theory and practice. $J$ of Public Admin Research and Theory 2008; 18(4):543-571.

28. Junior NB, Shimizu HE. Planejamento regional compartilhado em Minas Gerais: avanços e desafios. Saúde Debate 2015; 39(107):962-971.

Article submitted 30/05/2016

Approved 04/08/2016

Final version submitted 13/10/2016 